\title{
GAGE6 wt Allele
}

National Cancer Institute

\section{Source}

National Cancer Institute. GAGE6 wt Allele. NCI Thesaurus. Code C104474.

Human GAGE6 wild-type allele is located within Xp11.4-p11.2 and is approximately $7 \mathrm{~kb}$ in length. This allele, which encodes $\mathrm{G}$ antigen 6 protein, may play a role in tumor transformation. 